\title{
Journals of Trek of Barnes Family
}

\author{
EdTted by Joe H. BaLley
}

\section{INTRODUCTION}

From Boyd's Grove, Bureau county, Illinois, to California City, Mills county, Iowa, through southeastern Iowa, and westward skirting the Iowa and Missouri state lines, cannot be plotted on contemporary maps mainly because the "Alpha and the Omega" now are nonentities. But, that they existed and played a role in the westward expansion of our nation is shown by the travel Journals of Laura A. and Julius Barnes.

This man and wife were two of a company of fifteen persons that on a Monday in June, 1849, began a trek not to California but to Oregon. All in the troop were related by blood or marriage. They put their earthly possessions in prairie schooners and their faith in a Resurrected Savior, leaving home, friends and local church to begin life anew in the wilderness.

During these wanderings, rivers and creeks and ferries were enumerated as often and described more fully than the towns along the way. After two months and one week, plus five hundred miles of intuitive driving, the company reached the east side of the Missouri river, opposite the mouth of the Platte. Here they settled for the winter. It is this portion of the journals which follows.

But this winter season actually stretched into a lifetime. On at least two occasions Julius Barnes recorded his efforts to leave this particular claim-once to Missouri in 1867, and again to the Willamette Valley in Oregon in the late 1870's. Yet each time, he and his family returned to his New California or Florence.

Grateful appreciation is acknowledged to Mrs. L. G. DeBrohun, Franklin, Tennessee, whose sense of value has preserved these documents of her spouse's grandfather and whose motherly interest has permitted her 
eldest daughter's husband unlimited access to the manuscripts.

July, 1954.

West Texas State College

Canyon, Texas

\section{Journals $^{1}$ By LaURa A. ${ }^{2}$ AND JUlús ${ }^{3}$ Barnes}

June 25 (1849) 4

Started for Oregon. Princeville, Monmouth Spent the Sabbath east of it5

Monday. Mr. Barnes and Myself started from Boyds Grove Beauro Co. ${ }^{6}$ Illinois in company with Messrs. Dan, Ambrose, Georges Clark, and Waldo Tozier, with their families. ${ }^{7}$ We traveled three or four miles westward and encamped for the night on the prairie.. The cows were milked, the beds made, some in waggons, some in tents .. two men took their stations to watch the cattle, and the rest of us retired 8 our several places of repose.

26 We traveled toward the south, till about the middle of the forenoon, then stopped and breakfasted. In the evening camped near Mr. Day's, sold him two wooden bowls. ${ }^{9}$

27th We Journeyed south-east, south, and south-west, passed through Princeville, ${ }^{10}$ and pitched, ${ }^{11}$ four miles south-west of the village.

30th Saturday evening we encamped five miles east of Monmouth, ${ }^{12}$ on a small prairie.

Jly 1st Sabbath morning, the oxen were unyoked for the first time since we started... and about noon, one yoke of Mr. Barnes' oxen were missed, he hunted for them a half hour or more without finding them when he returned and four or five men of the company turned out with him and after hunt'n sometime

a visit of two ladies. beautiful flowers in Monmouth. Bees, brick house

\section{4th Jly Burlington ${ }^{5}$}

they were found, in the bushes but a few rods from camp, In the evening two ladies visited us, one a married lady with two children staid but a few minutes, the other was her sister perhaps 18 or 20 years of age a school teacher and a musician. She brought an accordeon 13 with her. I got the privilige of playing it some. She sung with us quite a number of our old singing school tunes. ${ }^{14}$ 
saw some pretty houses, and beautiful flowery vines over the door of one that was rather an ordinary looking house.

3d Tuesday we passed through Warren ${ }^{15}$ a small village, near a sand hillock. In this place I saw a large two story brick building, in one end of which were perhaps a half dozen oblong holes and bees, working, through the same, Tuesday evening we camped on a sandy plain, near a bluff, to the top of this, I ascended on the morning of the fourth of July, ${ }^{16}$ and saw burlington in Iowa. We arrived at, Shawkokwon, ${ }^{17}$ or "flint hills", on the east side of the mississippi, about eleven o'clock A.M., Hannah and Sarah Clark, Eunice Tozier and myself went down to the river shore and washed, but before we got out clothes dried, the old, and the new steam ferry boats, arrived, therefore we packed up our clothes wet, and got all things on board the new boat, and we went up the river at a very rapid rate, to Burlington, we got on shore and by pretty steady driving, we got to a camping place about two hours,

Sabbath Small grove oxen fell down on a slippery bridge after dark

July 5 th

Thursday morning we spread out our clothes to dry and some of the men went to Burlington to trade, and did not get back till two o clock. Consequently we traveled but a few miles this day.

Sunday July 8th 1849

Forty miles West of Burlington in the wilderness of Iowa. We traveled five miles to day for range and water and encamped for the Sabbath. We have been nearly two weeks on the road The vicissitudes of a journey by interrupting the regular practise of religious duties seem rather unfavorable to deep piety and communion with God but God has not forgotten us his mercy is still over us. While the pestilence ${ }^{18}$ has worked fearful destruction about us our lives have been spared. May God be honored in our salvation. We are on our way to Oregon. The toils and perils of the journey and the vaccillating nature of the human mind render it rather uncertain whether we shall ever get there but the Lord is good and we commit our way to him trusting that in infinite wisdom he will direct our steps.

July 8th

Sunday afternoon, all is peace and quiet now at our premises this morning I felt a great deal discouraged. on account of trouble and vexation. in consequence of our not being able to find on Saturday, a good place to camp on the Sabbath. Where we stopped last night, the grass was poor and the wood scarce, and no water near us for the cattle. However, we managed to get wood and water enough to cook 
our suppers and wash our dishes. this morning we arose, ate a cold breakfast, and started. After traveling 7 or 8 miles across a fine prairie, we arrived at a small grove where here was plenty of wood and water, but rather poor grass, in the grove we had a little controversy about stopping there for the rest of the day. Mr. Barnes and I wished to stop, but the rest wished to go through the grove, so we gathered a lot of hickory bark for fires and came on. The road was quite wet and muddy, for it had been raining nearly all the forenoon and in crossing the plank bridge our wheel oxen 19 slipped very bad and fell on to their knees several times. Old bright looked as if he would break his neck it was a hard...

cholera. Meloncholy. Consolation.-Theosaqua.20 Desmoines ... place to get on. for it was four or five inches perpendicular stone at the end of the bridge, and sloping and muddy below but Mr. Clark and George came and helped get the wagon on to the bridge so that we got along safely at last, and camped on the prairie within a few rods of the woods and creek. This afternoon I felt bad and melancoly in consequence of hearing of the colera, spreading all through this part of the country; (We have been in two villages where it rages to some extent, Viz: Burlington, and Washington ${ }^{21}$ ) and in consequence of suffering my mind to be too much taken up with worldly matters. Moving is very trying to my spirit. Sabbath evening I found great consolation and comfort in reading the 65 and 66 chapters of Isaiah, and felt thankful for the great and precious promises I found there. O that the Lord would grant me grace to think upon him more, to love him, more, and serve him more devotedly. The forenoon of this day was not much of a sabbath to me: and I fear that non of it was spent as a sabbath should be, by many of our company ,O that the Lord would grant us all "grace to know and do His will."22

July 9 In the morning we passed over some tolerable prairie country but much of it is too flat. In the afternoon we traveled through the broken timber land on the Northern slope of the Des Moines valley. The valley itself is beautiful. In the evening we arrived at ( $\mathrm{H}$ ?) eor(?) aque ${ }^{23}$ The ferry was difficult from the steepness and roughness of the banks and the ferrymen appeared lazy. So we went up the river $1 \frac{1 / 2}{2}$ miles to a ford and encamped for the night.

9th Monday-evening,

We passed through Theosaqua, ${ }^{23}$ and instead of being ferried across the Desmoines, went up the river and Camped two miles above town in a low bottom Just back of a high embankment, at an old

July 9th Deserted House

Forded the river 
ford. It was in the dusk of evening when we stopped, and were all very tired; therefore we went to bed supperless. It was a gloomy place Close by a deserted house. the fence was nearly all taken away from the feild which was overgrown with May weeds. The place had the appearance of having been formerly occupied by enterprising peopiles. but they were all gone whether by death or moving away on account of sickness, I know not. It was a snug little frame house neatly shawled with some kind of forest trees.

July 10 We waded and examined the ford and found it about $3 \frac{1 / 2}{2}$ feet deep in the deepest part. We raised the wagon boxes ${ }^{24}$ about 6 inches and put blocks underneath to keep them above water. We then hitched three yokes of oxens to each ox wagon and with three teamsters, one on the off side, 25 we went safely through; but the first wagon nearly turned over in the mud as we went out. We then cut brushes and laid down so that the other wagons got out more securely. The Des Moines is three to four hundred yards wide flowing with a brisk current over a bed of rock, gravel, and sand between rocky banks. Our company, men and women, waded through, and had a good frolic in the beautiful river. We then traveled 4 or 5 miles over woody bluffs and encamped on an unimproved 80 acre lot in the midst of a settlement.

10th Tuesday morning our men folks waded the river to see if it would answer to drive in with the wagons. they found it pretty deep, but concluded to try it. and went to work and cut some blocks, and false bolsters, ${ }^{26}$ and raised the waggon boxes to prevent water from running into them. After the waggons and cows were all over, the men came back and led the women across; the watter was warn and pleasant, but it was waist deep part of the way and ran so swift we had hard work to keep our course. But when we got near the opposite shore, where the water was deep, and less swift, our husbands gave us lessons in swimming, but in my first attempt at that exercise, I plunged, head and bonnet into the water, and came up as much affrightened as a chased. Rabbit. But in my second I was more

Mecanies-burg School house Davis Co handsome Country Ioway

successful. We could not however spend a great deal of time, in frolicing therefore we hastened to our waggons changed our clothes, the men took out the blocks and let the boxes down, and we started and got to a camping place a little after sundown within 8 miles of Keosauqua: but thought we had done better than we should have done, had we crossed at the ferry; for the boat was small, and propeled at a very slow rate $\mathrm{A}$ few minutes before camping, we passed through Mechanicsburg27 
and found a mud hole so bad that our team could not draw the waggon through without the help of another yoke of oxen.

11th A very warm day. We passed through some fair prairie country in the morning. At noon we rested under some trees on the bank of fox river. In the evening we passed through Dover ${ }^{28}$ and some beautiful prairies newly settled: the houses generally built of logs. We encamped on a grassy ridge with a run of water and a spring North of us.

July 11th Wednesday:

We started this morning before breakfast to find water for the cattle, and arrived at a small creek near noon where we stopped and cooked our breakfast and let the oxen rest an hour or so, for it was a very warm day. We passed a school house, and a meeting house: this morning, and met a lot of children going to school.

12 Beautiful prairies and timber land continue. Very warm at noon. In the afternoon we had a light shower. We have now seen the famous Des Moines country. It is newly and thinly settled, the houses generally poor and it might be difficult to assign a sufficient reason why emigrants should prefer it to Illinois. One of our company remarked that "If we could find a country as much better than Illinois as Illinois is better than Iowa it might do for us to settle there."

\section{2th Thursday}

Yesterday afternoon and to day in the forenoon we passed through a handsome region of country in Davis County: Iowa: it would compare verry well with Illinois. It has but a very small portion of all that I have seen of this state before, that is near as desirable

July Less desirable than Illinois Valley of the Chariton for a residence, as Illinois, with the exception of water, the well water of Iowa as far as we have come is generally excellent. Afternoon, the weather remained very warm, till toward night, when it rained, and the air became cool.

13 To day we crossed the prairie between the Fox and Chariton rivers near their heads. The prairie is good and the timber on the borders is tolerable. We crossed Fox river in the morning. It is a small dirty stream where we crossed it but the valley is well wooded. We have seen but few houses to day.

13th Friday morning was quite cold. We crossed a 16 mile prairie to day which was mostly unsettled. and camped on a high prairie near a small creek.

14 This morning after two miles drive we came to the bluff where we had a view of the Chariton Valley. ${ }^{29}$ The broad low prairie embossed among woody bluffs with the dark line of timber along the Chariton and the fringes of trees intersecting 
it in various directions presented a landscape of native lovliness and beauty rarely or never surpassed: but say nothing of the muddy crooked road and the swarms of biting flies which we and our beasts found in that bottom. In the afternoon we traveled among the bluffs well wooded with a small growth of timber chiefly oak and hicory with a few log cabins along the road: inland, lonely, poor!

14th Saturday morning the weather was very cool, we were on our way in tolerable season: and after traveling a few miles came to a bluff from the top of which we had a most delightful view of the valley of the Chariton River. which valley was a flat prairie about three miles long and two miles wide, where viewed from the bluff, and divided into two parts by a long dark line of timber passing from the edge of one forest, across the vale to the edge of another, But in this beautiful vale, we found a very bad road, and a great quanitily of flies which tormented the cattle dreadfully and we were glad enough to get out of it. We have had a great deal of very rough road since we came into this state,

Bad road Over prairies through raveens. Came into Missouri. Bad road Princeton

we have also had some very good road. In the evening we camped on the edge of a prairie, near a small farm.

15 Sunday. We traveled seven miles to-day and encamped in a small hicory grove where our stock could get water where we remained the rest of the day. No house is in sight. The field of nature unaltered, except by a dim road and a few stumps lies before us.

"O solitude where are the charms"

The day is cool and pleasant. The woods and prairies are green and fair. But let me swell among my fellow men. What has God for me to do in the Wilderness.

\section{July 15th}

Sabbath morning, we breakfasted did our chores sang awhile and as there was no water near for the cattle, came on about seven miles, where we found a small creek, which we crossed, and stopped in a little grove on the hill for the sake of a shade, and good air.

16 In the morning we crossed a wide prairie: in the afternoon among the hills and vales \& stumps \& flies of Locust Creek $^{30}$ we entered the State of Missouri the soil sandy. the timber good.

16th Monday our course to day was over prairies and through groves and ravines, with corn and oats growing by the wayside. We found the flies very bad on one of these prairies. There is a cool refressing breeze from the 
north east but the sunshine very warm. Late in the afternoon we came into Missouri.

17 Hills and vales timber \& prairie; few houses and farms. plenty of flies and a rough muddy road.

July 18th This day we crossed a branch of locust Creek and a tract of country well proportioned to prairie \& timber. In the afternoon we passed through the Morgan Settlement ${ }^{31}$ and a dense forest five miles wide, and encamped on a low prairie west of Princeton, ${ }^{32}$ the log county seat of Mercer County.

19th We forded an Eastern branch of Grand river33 this morning. It was a hard pull among the rocks. A saw and grist-mill were near the place. In the afternoon we traveled through some tolerable fair hilly country. We encamped late in an extensive forest on the East bank of the East branch of Grand River.

\section{9th Thursday morning. .}

we have now traveled two days a upward

in this state and have found a very bad road this is a very hilly country. the roads generally are very crooked stumpy, muddy, and stony. We have found some very good road however and passed over some handsome prairies. But the houses are nearly all poor log cabins. Last evening we traveled throu' several miles of timber, and passed through princeton the county

Two large rattle-snakes-pretty farms 2 negroes. Camped in depth of a forest Middle fork

seat of 34 County. and camped on the bottom prairie of the east fork of Grand river. This morning we started before breakfast got to the river bank quite late in the morning but found the ford impassable without digging down the bank. Therefore we got breakfast while Mr. Clark worked on the road; while here $\mathrm{Mr}$. Barnes killed two very large rattlesnakes; the longest one measured 3 feet an inch and ahalf, without the rattles. I heard that a few days ago a little child was bitten, and died in about two hours. Afternoon. About the middle of the afternoon we passed some pretty farms, but the best looking one had eleven log buildings on it, one of which was a large log barn. I think that saw mills must be very scarce in this part of the state, as the houses are all block houses. ${ }^{35}$ On this farm I saw two negroes: the one perhaps 15 and the other 9 years of age. In the evening we traveled a long time in a thick forest in hopes of being able to get through on to the prairie to camp but had to stop in the depth of the forest finally: wher the musquetoes and gnats disturbed our slumbers very much.

20th This morning we crossed the bottom in a muddy crooked road and forded the stream about $2 \frac{1 / 2}{2}$ feet deep. It was a pretty 
good ford. The tallest black walnut tree I ever saw was in that bottom. We then had a hilly road for some miles among prairies \& clumps of brush. We crossed one nice prairie towards evening and encamped on a knoll with timber $1 / 2$ a mile west of us. We passed but two houses today and there is one farm now in view. Here is room for many people.

\section{0th}

Friday morning we started before breakfast and traveled several miles through the woods and over a small swampy prairie and crossed the middle fork of Grand river; where we stopped and breakfasted about noon on a prairie, after which we traveled through

Rough road handsome prairie, little groves Names on racks high rolling prairies

raveens and over hills rough and stumpy but at length we came to a reasonably level prairie, crossed one gravely creek with considerable drift wood along its banks Where we got wood and water for the night; this prairie is handsome dotted with little groves and short lines of timber along the margins of the brooks. This afternoon we passed some rocks on the hilside, on which names were engraved and dated April 1849 probably by persons who had started for California, to dig gold. We camped on the same prairie when the sun was a half hour high.

July 21 We traveled 10 or 12 miles to day passing throu the seat of Harrison County ${ }^{36}$ and across Big Creek a good mill stream on which we were told a silver mine has been discovered and also throu broken country. We see but few Inhabitants and a large proportion of them express themselves dissatisfied with their location. To a person fond of refined society and a highly improved country it is not a very desirable residence.

July 21st Saturday; this morning we got quite a late start-and traveled but about ten miles to day (on account of being hindered with a lame horse, which was lamed by drawing hard over a ruff road) and camped on the e (d) ge of a very rolling prairie in sight of a farm that is about three miles distant; in coming to this place we came over some very high rolls from the tops of which, we had a fine view of a handsome country but this is far inland and the inhabitants are poor and very ignorant and this is no place for me I would never be contented here.

22 Sunday. O how grateful to the weary for a day of rest! The rain has been falling moderately all day. Our tents and wagon covers but imperfectly shelter us but still it is a day of rest. Poor fallen man, naturally prone to sin, needs a special season when he may turn from the low cares of life to com- 
mune with his maker and seek counsel and aid from the Author of his life being. Evening. The day passes away. The rain has ceased. The declining sun and the fading light may be likened to that time of life when the vigor of manhood is past and man goes silently away to his long home.

July 22nd

Sabbath morning, it was raining when I awakened and rained nearly all day but we had a few visitors; one of them

Gentry ville Kentuckian pleased with the accordion incessant rain Return of gold hunters

a man from Clay County Kentucky staid several hours and was greatly pleased with the music of the Accordeon as he never saw one before.

July 23 A rainy day. The road muddy and slippery. We remained in camp this day. In the afternoon we saw two homesick young men on their return from Fort Laramie. 37 They had started for California. They said that the road was good across the plains.

July 23d

Monday morning it rained before we arose and continued to rain almost incessantly for an hour or to when it stopped and we got our breakfasts did up our work and are now waiting for the water to soak away so that we can travel, there is quite a pleasant breeze from the east this morning. This afternoon some of the men went out and killed some wild turkeys. We had lots of visitors to day among them were two men from ft Laramie who had gone that fur on their way to California, and could go no further on account of the great numbers that had gone before them. They said there were 45,00 voyagers before them, and when coming back they met 6,000 more. ${ }^{38}$

24 Rainy in the morning, our teams lay idle today. I went after the rain with $\mathrm{Mr}$. Clark four or five Missouri miles (nine statute miles) to a mill on Big Creek owned by a Mr. Watson to find a place and employment for the Winter. But we did not find the man.

24th Tuesday came in with rain which lasted several hours, We are still in the same place, where we stopped Satterday night.

25 We traveled nine or ten miles over a rough road. We passed the old Nevill place, crossed Sampon Creek and encamped at sunset on a high prairie.

25th Wednesday We started late in the morning and traveled eight or nine miles during the day.

26 Some of the company much discouraged with the road, 
the country, and the people, in favor of returning. However after some windy talk we all went on about six miles to Gentryville on the West Fork of Grand river where we stopped for the night. A grist and saw mill, several stores, and mechanichs of various kinds render Gentryville ${ }^{39}$ the most flourishing and businefs 40 like of any town that we have seen west of Burlington. The people appear to be civil and obliging.

26th Thursday we arrived in Gentryville, situated on the west fork of Grand river, toward the close of the day, and a first object of particular interest that presented its self to my view,

Lulled to repose by the music of the water. forded the west was a young negro lassie about 9 years old I should think, who lifted the window curtain in the twinkling of an eye and grinned at us, then let it fall again as quickly. We encamped on the bank of the river a few rods below town where we were lulled to repose by the music of the waters as they tumbled over the mill-dam.

27 In the morning I had a long hunt for cattle but did not find them. Some of the company found them soon. We raised our wagon boxes about a foot and forded with horses and drove the cattle loose and had some things wet and damaged at that. We drove about six miles and encamped on a large prairie.

\section{7th}

Friday morning, Mr. Barnes had some trouble about finding his oxen for the grass was very poor about us and they had rambled off we knew not where, but they were found some distance up the river. Some of the cows also were found several miles above town on the prairie. The men concluded to ford the river, below the mill although it was pretty high and was still rising on account of the recent rains. So they raised the waggon boxes some of them a foot above the bolsters, but never thelessSome of our things got wet and damaged. The horses draw all the waggons across for the water was so deep and the current so swift that the oxen could not, but were driven in with their yokes on, the cows also went with them, some got along well enough, others got into deep water and floated down stream paddling for the shore as they went and succeeded so far as to get within reach of one on an island and were helped unto it; the water was shallow

camped on a 20 mile prairie Good road a great treat Taylors farm between this island and the mainland, so they got out without further difficulty. our leaders started to wade across, but one of them cowered and pushed the other around so that the current took them in deep water where they swam and 
floated along down stream and finally found footing on the same side, and stood in the water among the bushes untilMr. Barnes found them. and while he was unyoking one, the other got away with the yoke, swam over, and was helped unto the island, the first went up to the regular ford and waded strait across; It was late in the day when all things were over, therefore we stopped in the first good place we came to; which was on a high prairie 20 miles wide, got our suppers and then traveled till after dark.

28 Twenty miles to day. a good road, good rolling prairie, and in the evening a small creek with a little scrubby timber about it. We encamped on a good prairie with a farm a few rods West of us.

\section{8th}

Saturday we traveled 20 miles over a good road which was a great treat. In the afternoon we crossed one creeek which had some timber along its banks, and encamped on a five mile wide prairie a few rods west of a Mr. Taylor's farm.

29. Sunday. Again the day returns which commemorates the Resurection of a Crucified Savior. Precious beyond earthly value is the Christian hope. In this world we have tribulation griefs whose severity is known only to the sufferers abound. We are often disappointed in our earthly hopes. Our days pass away as a shadow. The Saviour fully offers us rest for tribulations, comfort and joy, for griefs, a Heavenly mansion, and Eternal Life. We lie encamped on a prairie $1 / 2$ of a mile West of a farm owned by Mr. Taylor.

29th Sunday we had several thunder showers near the middle of the day, but we had some pleasant weather, and a chance to read and meditate and commune with our God. Even on a journey in the wilderness we have a day of rest.

Little Platte Talk of buying a crop Savannah A point not to work the road

July 30 We came eight miles over a tolerable country of prairie \& timber, crossed Platte River41 at Kibbeville and encamped near a farm on which we talked of buying a crop of corn and hemp.42

July 30th Monday morning our company joined and bought a sheep of Mr. Taylor and divided it each family having a share. We traveled seven or eight miles, and forded the little platte Just below Kibbies Mill at Rochester.43 This is a very pretty stream with a smooth rocky bottom. We stopped to bate (? $)^{44}$ for noon near a farm, and spent the rest of the day here. The men off scouting about to look at the 
place, they talked of buying out the reinter; but all were not suited with the clamce. (claims)

31 In the forenoon we traveled over a hilly region with farms interspersed Some of the road through the woods was so crooked and bad that it was scarcely possible to get along. About noon we passed through Savannah45 the seat of Andrew Co. In the afternoon we passed through a well settled region and encamped on the side-hill of a close fed prairie facing Southward. Mr. Miller who joined our company at Savannah got his wagon fast in the mud near by.

31st Tuesday a little afternoon we arrived in Savannah the county seat of Andrew Co. They have a fine Court-House here and a tolerably good looking Meeting-house. I perceive that gambling and drinking of strong drink is prevalent in this state. In Savannah I heard the ball rolling in the ten-pen-alley building. Mr. Miller with a load of store goods joined our company in this village for the purpose of being helped up the hills and through the mud holes by our teams, for the people of northern Missouri seem to make it a point not to work the roads so long as it is possible to pass them. We encamped for the night about five miles from Savannah, on a prairie of short grass near by $\mathrm{Mr}$. Miller got his wagon stuck in a mud hole that all the rest escaped, this was probably in consequence of drinking to much whiskey.

August 1 We traveled over hills of prairie \& timber laid out in beautiful farms, through a small town called Newark,46 across the Nodoway 47 River by ferry, five or six miles through woods and prairie and encamped near a small grove N.E. of us.

August 1st Newark Polyss ferry Arrived in the Missouri valley

Wednesday we passed through Newark a small mean looking town with a meaner set of inhabitants in all probability. Crossed the Nodawa at Polly's ferry, Camped at night on a prairie with a small grove a few rods at our right, and two or three farms in view at our left.

2 Our route was over hilly prairie with but little timber and few settlers. In the evening we arrived at the Missouri Valley and encamped on a hill where we had a splendid view of the wide prairie bottom, and where the moschitoes harrassed us all night. An Indian of the Stockbridge 48 tribe joined us at this place for the night. he was from Fort Leavenworth with a pony on some errand up the Missouri River. $\mathrm{He}$ was dressed like white people and spoke good English. $\mathrm{He}$ amused us much by fiddling and singing and whooping.

2nd Thursday we traveled over a fair prairie and had a good road. Arrived in the valley of the 
Missouri River late in the afternoon got water at Mr. Jacksons, passed the store where Mr. Miller left his load, ascended a hill and encamped for the night and to look about for business and a place to winter.

3 This day we looked about the neighborhood to ascertain if it would be a good place to winter. I do not much like the prospect: plenty of grass, few inhabitants building timber to be hauled seven miles.

3rd Friday was spent in thinking and talking about going to work for the merchant at the foot of the hill who made a good offer but the place is not liked very well by the most of us.

4 Waldo and I went to Oregon 49 the seat of Holt Co. We found a small town, plenty of business, but no rooms or houses for our families.

4th Saturday Mr Barnes and Mr. Waldo Tozier started on horse back in the morning for little Oregon 49 12 miles from this place to see what the prospect is there. In the evening they returned and brought rather an unfavorable report of the place.

No religion or good morals Left Lemans Arrived at the Missouri

Aug. 5th Sunday. We remained encamped on the bluff overlooking the wide valley of the Missouri. We have ascertained that men here as elsewhere are prone to immorality and need the purifying influence of the Gospel of our Lord Jesus Christ. This country is rich in natural resources, but the Minister of the Gospel would perhaps find but a meagre support. In view of this the Disciples of our Lord in this Country should be doubly dilligent and devoted that the blessing of God may rest upon the people of this fair land.

6 Some rain to day. In the afternoon I waded about a mile through the grass in the bottom. Much of it is blue joint50 more than a yard high. I then examined a grove of timber a mile \& a half from our camp. It was rather inferior in quality.

$7 \mathrm{Mr}$. Clark. Waldo.Ambrose and I went 5 or 6 miles into the bottom. We found some splendid Cotton wood Timber, also Sycamore, White Popular Thorn Locust and Willow. The pea vines were matted 2 or 3 feet deep over much of the ground. We crossed Squaw Creek \& Little Tarkeo \& Big Tarkeo. ${ }^{51}$

Aug. $8 \mathrm{Mr}$. Clark \& Waldo Tozier went 12 miles to get business at a saw mill but they were unsuccessful. I worked some on my melodeon, 52 and lost some time.

9 Home sickness prevailed through a part of our camp 
this day. The refinement and religious privileges of the more Eastern States were remembered with feelings of regret. In the evening the mental atmosphere was rather clearer and we generally concluded to remain through the Winter.

10 Mr. Clark, Waldo \& I moved our wagons partly down the hill for a better \& more permanent encampment. Ambrose and George moved into a house near at hand belonging to Mr. Leman, a merchant.

11 Several of our company went a new route to see the River timber. The grass was deep enough to Bury the horses and wagon, they could not cross little Tarkeo. There was not much good timber this side and the flies are so bad that no team ought to be driven in there at this time of the year. I did not think it a very favorable prospect for wintering.

August 12 Sunday. The day returns for rest from toil. I am far from the temple where God is worshiped in spirit and in truth. The foul spirit of Slavery broods over this fair land.53 Can God be merciful to a people who legalize every species of crime against their fellow man? Truly the prospect to the philantropist is dark. But God is mighty. and may "He with the two edged Sword" van quish the oppressors and turn the nation to righteousness. In the forenoon we had a shower. and in the afternoon a tempest with a copious rain.

13 I am a stranger in a strange land. I have not done much this day for head work. Why should I spend my strength for nought? I had rather loose my time in idleness than in exhausting labor.

14 I have partly consented to remain in this place during the Winter. In the forenoon I commenced haying. About noon three wagons of returning Californians passed us. They had been 130 miles beyond Fort Laramie.

15 We went into the bottom after house timber.

August 19th Sabbath evening we are still on the bluff which overlooks the valley of the Missouri, We have not had the privilige of attending publick worship since we started. This part of the state seems to be rather destitute of religion and good morals, though some of the inhabitants tell us they want a town built up here of good respectable people and they wish our company to stay and settle in town and build them a school-house large enough to hold meetings in.

Aug. 23 Mr. Clark and I have been a week on an expedition through the Pottantomie Purchase ${ }^{54}$ in search of a better location. What few inhabitants we found were generally Mormons. They for the most part wished to sell their claims that they might go to Salt Lake Valley. The country is scantily 
supplied with timber. The land is good rolling prairie abounding with springs and rivulets of pure water. We ascertained that good claims could be made or purchased on easy terms and we then returned to our friends in Holt Co. Mo. To day we had a long hunt for our oxen and succeeded in finding them.

24 We packed our goods and started about 11 o'clock for the upper country which was the occasion much rejoicing to some of our company. Brother Ambrose had been at a liquor store so long that he was incapable of driving his team.

24th Friday we started from Leman's (the Merchant) in company with Mr. Stuart, for the western part of Iowa.

25 Very warm. We only traveled about ten miles over hills \& vales crossing Big Tarkeo \& a muddy bottom. We encamped near a well 100 feet deep.

Aug. 26 Sunday. In the morning rainy and quite cool. About ten the rain ceased and we traveled forward about 8 miles which I fear we were not justifiable in doing. Oh for a home where I can properly observe the Sabbath and enjoy christian fellowship and communion. We encamped a mile West of Rock Creek on high prairie. the weather cool and pleasant.

27 We had a long hunt for the oxen and finally found them quietly reposing in the thick bushes. We then traveled eight or nine miles among the bluffs, crossing the lin between Missouri and Iowa in sight of the Missouri River and encamped near a large field south of a wood. Clear. pleasant weather.

28 We crossed the Nishenebodena river ${ }^{55}$ by ferry and about six miles beyond we encamped in the valley of the Missouri among a host of moschitoes. The weather is fair, cool, and windy. 12 miles to day.

29 Our oxen left us last night and we could not find them till too late in the day to start. In the evening we had a thunder storm.

Aug. 30 We traveled along the foot of the bluffs over beautiful farming land and many claims with good springs of water for sale cheap. In the evening we crossed the bottom prairie. We had some watery places and bad bridges. We encamped by a dry pleasant farm near the river.

31 Our route lay up the river over much good dry prairie with timber convenient. We also crossed (K?)eg creek ${ }^{56}$ and some inundated land. In the evening we penetrated a quarter of amile through thick woods and came upon the bank of the river at the cabin of Mr. Stuart which is opposite to the junc- 
tion of Platte River where we encamped intending to seek a location.

31st We arrived at Mr. Stuart's place, (situated on the Missouri river, in Pottawatamie County and directly opposite the mouth of the "Big Platte") late in the afternoon.

September 1 The South wind blows, the Sun shines, the air is cool and delightful. Our company seem pleased and tranquelized by the scenery. The broad river with its islands and shores forms a scene with they are not familiar but with which most of them seem favorably impressed. Ambrose \& George purchased from Mr. Stewart a claim ${ }^{57}$ of $16($ ?) 0 (either 100 or 160) acres opposite the mouth of Platte River for which they pay two hundred dollars.

September 1st

buying of Mr. Stuart.

The men looked claims some thinking of

Sept 2 Sunday Sunday I attended a Mormon meeting where I heard Mr. Joseph Young ${ }^{58}$ preach the doctrines of the Latterday Saints. The meeting was heald about three hours. The exercises resembled those of a Methodist meeting. After singing and prayer the preacher read a part of the fiftenth chapter of the "Book of Covenants" which seems to be a mixture of altered passages of Scriptures and the "Revelations to the Saints" The discourse was founded upon the portion of the "Book of the Covenants" which was read. The theme seemed to be that the "Saints" have the witness of the Spirit that the "Book of Mormon" is true. The Faith seemed to me a speculative scheme of salvation rather than that "Faith" which works by love and purifies the heart.

$3 \mathrm{Mr}$. Clark and Waldo Tozier purchased a $\operatorname{claim}^{57}$ from Andrew I Stewart half a mile above the mouth of Platte River on the opposite side of the Missouri. I alone of our company am not located.

Sept. 4 This day I accepted a claim to an acre on the bank of the Missouri opposite Platte and commenced clearing away the bushes and vines. In the afternoon I rode about with Mr. Stewart.

5 I cut and burned bushes and vines. I am far from the old haunts of civilized man. Last night I heard the Indian drum $^{59}$ and their yells under the excitement of the dance.

October 19, religious meeting Confession of sin, Prayer for pardon

Sunday ${ }^{60}$ we met together at brother Waldo's for a Social religious meeting, and I greatly rejoiced at the manifestation of the presence of God, working by his 
Spirit, upon the heart of our brother George, Who arose and witnessed to the goodness of God. He seemed to be under great excitement, so much so, that it was with difficulty that he could talk. This was the first meeting we have attended, excepting a Mormon meeting or two, since we left our home in Boyd's Grove, and I think that we were greatly blessed, in the first attempts.

6 From this date (September, 1849) onward to the 15th of January (1850) I did not keep a regular Journal. I built a hay shanty, made and stacked hay for winter, drawed61 logs for a house, helped my neighbors about building, and on the 6th of December (Saturday) my shanty took fire and burned down but by wonderful good fortune my friends and myself saved my property with the exception of about twenty dollars worth. I gave a yoke of oxen for a part of A. I. Stewart's claim and engaged with several others in laying out a town which we call California62 City.

\section{NOTES}

1. These records, in two separate books, are journals, day books, or logs of travels of a husband and his wife and cannot be classified purely as personal diaries. They are now in the possession of Mrs. L. G. DeBrohun, Franklin, Tennessee.

2. Laura Augusta Barnes, nee Langworthy (January 17, 1825- June 23, 1852) began her journal on the first day of the trip. Her entries are indented to the middle of the page throughout the paper. When she and Julius Barnes, her husband, have an entry for the same day, the husband's comments are recorded first.

3. Julius Barnes (January 15, 1815-March 15, 1906) was the son of Anson Barnes and Orpah Hale. He was born near Tarrington, Litchfield, Co., Connecticut, the oldest of a family of nine. In $1823 / 24$ his family moved west to Erie, New York, after having resided in Delaware, County, New York, for several years. At this latter place Anson Barnes died, and his mother married Dan Clark (q.v. \#7). After a few years they traveled west again to Licking Co., Ohio, and then to Bureau County, Illinois. From Barnes, Em$\mathrm{ma}$, Unpublished Manuscripts, hereafter referred to as Mss, and Barnes, Julius, Journal.

4. Nowhere in her beginning journals does Mrs. Barnes identify the year. However, the dates and the days of the year 1849 coincide; her events correspond with Mr. Barnes' Journal when the two are placed together; and events marked a year later in her book show that the initial year was 1849 .

5. At the top of each page Mrs. Barnes wrote items to remember. These phrases always give a forecast or a synopsis of ideas later described.

6. "John Dixon, the brother-in-law of Charles S. Boyd, came to Bureau County in 1827, locating in the south part of Arispee township. Mr. Boyd, in going to and from Galena [Ill.] would stop at his place, and taking a fancy to it, purchased the claim and the locality took the name of Boyd's Grove ... When Charles S. Boyd removed to his new place [1830] there was not another house within twelve miles. It was that distance to the nearest house on the north and 
eighteen miles to the nearest house on the south. His home was on the stage route from Springfield to Galena, which passed through Peoria, then known as Fort Clark. Here [Boyd's Grove] the stage stopped for refreshments. ${ }^{33}$ The Biographical Record of Bureau, Marshall, and Putnam Counties, Illinois. Chicago, S. J. Clarke, 1896. page 156.

Boyd's Grove appears on a list of new post offices in the Springfield (Illinois) State Journal, 8 February 1834.

Note: Mrs. Barnes spelled many items phonetically. That she was an apt pupil and willing to change can be noted throughout the work. When she changes "verry" to very, "ruff" to rough, "Ioway" to Iowa, or "raveen" to ravine one can conjecture that Mr. Barnes read and corrected her spelling at each entry. That the reverse of this is not true might be shown that only once did Mr. Barnes change his idea of a spelling: "hicory" tree finally becomes hickory toward the end of this section.

7. Persons known to have made the trip include Mother Orpah Hale Barnes Clark and husband Dan Clark; her son, Julius Barnes and wife, Laura A.; her Clark sons and wives, viz., Ambrose and Hannah Theresa [Coulson]; George and Sarah Ann [Coulson]; and her daughter Eunice Matilda and husband, Waldo M. Tozier. Others in the company included an unmarried son, James H. Clark, and a daughter, "Aunt" Cordelia A. Barnes, Emma, Mss, records fifteen, "including the children," making the trip. The family Bible records only "Clarissa M. Clark" [1844-1852] as a grandchild living during the "1849" period. She was the daughter of Ambrose and Hannah Clark. A letter from Anson V. Barnes, Licking Co., Ohio, 1843, to his brother Julius Barnes in Bureau Co., Illinois, adds this post script: "Tell George (a Clark and a half-brother ) that Eliza \& Elmira are fine girls." Though it is not certain which three children made the journey, in all probability it was "Elmira and Eliza" and the gandchild Clarissa.

8. Shows that the word was deleted by the writer.

9. "It was during this winter [1842-43] that he [Julius Barnes] put into execution the plan of turning wooden dishes [bowles] as a means of providing the necessities of life. After considerable difficulty and with the aid of a friendly blacksmith who lived about 10 miles distant he succeeded in constructing a lathe to run by footpower with which he could [make] wooden bowls. After making up a supply of bowls he would get a horse and wagon from a neighbor and take them about the country and sell them or sometimes exchange them for provisions of various kinds." Mss.

10. Peoria county, Illinois, 22 miles NNW of Peoria. From Boyd's Grove to Princeville (population in 1850, 500) one would follow Spoon river. Lippincott.

11. An example of a correction [Julius] but misplaced.

12. The present county seat of Warren county, Illinois, named in memory of the Revolutionary War battle of Monmouth, New Jersey. Illinois Guide. Its population in 1850 totaled 797.

13. It is known that Mr. Barnes had a melodeon [Aug. 8th Journal entry] on this trip. Could he have traded bowls for this accordion? [See July $22 \mathrm{~d}$ entry of Laura Barnes.]

14. [J. Barnes] "taught the old fashioned singing school a number of times. He had a great fondness for music and was able to play several different instruments." Mss. The following singing school book still is in the family: Webb, G. J. \& Mason, Lowell, The Odeon, secular melodies, arranged and harmonized for four voices, 
designed for adult singing schools, and for social music parties, 5th edition, Boston, Wilkins, Carter, 1847.

15. The U. S. Postal Guide, 1831, gives Warren as Warren Court House, Post office of Warren county, Illinois. The U. S. Census, 1850, lists Warren in Henderson County, Illinois, population 92.

16. Events in the United States in the 73rd year after 1776 include:

Jan. 18 The Astor Library, New York City, incorporated

Feb. 8 N.Y. Tribune listed 131 vessels sailing for California with over 8,000 passengers for the gold fields.

Feb. University of Wisconsin opened.

Mar. The Salt Lake City Convention to frame a system of government called. State of Deseret [Mormon] formed.

Mar. 5 Inauguration of Pres. Zachary Taylor and Vice Pres. Millard Fillmore.

Mar. 18 Charter granted to Pacific Railroad to build a line from St. Louis to Jefferson City [no railroads in Mo. until 1852]

Jun. 15 Death of James K. Polk of cholera.

$$
\text { -Keller, Dictionary of Dates. }
$$

17. Sho-kekon or "Flint Hills" was the Indian name for the site.

18. In 1840 cholera apepared around Calcutta, India. The East India Company sent an expedition into China. Simultaneously cholera appeared. By 1846 it had spread into Central Asia. Mecca Pilgrims carried it into the Mediterranean and the trade routes to Europe. Over one million died in Russia during the 1847 and the 1848 plague France lost 150,000; Germany had untold mortalities. In 1848 Europe sent 300,000 emigants to America. Immediately all of the inland trade and water routes were affected. The U.S. Census, 1850 , records 37,034 deaths this year of cholera, or $13.32 \%$ of the zymotic disease deaths in the United States.

19. Wheel oxen are work oxen, whether it be those pulling the load of a wagon or those treading the saw or the grist mill, as distinguished from the milch cows.

20. Theosaqua, Keosauqua, or "Great Bend." Settled in 1836. Site of the cause of the "Honey War" of 1839, between Iowa and Missouri. Iowa Guide. The Missouri Historical Review 3:273-74, July, 1909, reprints the following from the Palmyra Whigg, December 26, 1839:

\section{The Honey WaR}

By John I. Campbell,

Tune: "Yankee Doodle"

Ye free men of the happy land,

Which flows with milk \& honey,

Arise! to Arms! Your ponies mount,

Regard not blood or money.

Old Gov. Lucas, Tiger-like,

Is prowling round our borders;

But Gov. Boggs is wide awake,

Just listen to his orders:

Three bee trees stand about the line,

Between our State and Lucas,

Be ready all those trees to fell,

And bring things to a focus.

We'll show old Lucas how to brag,

And seize our precious honey;

$\mathrm{He}$ also claims, I understand,

Of us three bits of money.

Conventions, boys, now let us hold, 
Our honey trade demands it;

Likewise, the three bits, all in gold,

We all must understand it.

Why shed our brother's blood in haste,

Because big men require it:

Be not in haste our blood to waste,

No prudent men desire it.

Now if the gov. wants to fight,

Just let them meet in person,

And when noble Boggs old Lucas flogs,

'Twill teach the scamp a lesson.

Then let the victor cut the trees,

And have three bits of money,

And wear a crown from town to town,

Annointed with pure honey.

And then no widows will be made,

No orphans unprotected;

Old Lucas will be nicely flogged,

And from our lines exected.

Our honey trade will then be laid

Upon a solid basis

And Gov. Boggs, where'er he jogs

Will meet with smiling faces.

21. The present town of Hillsboro, Henry county, Iowa, changed its name from Washington about 1851. ANNALS OF Iowa, “Abandoned Towns," a series in the 1930's by D. C. Mott.

22. Throughout the log quotation marks are used sparingly. However, when they are included, the closing marks are on the line of punctuation and not above the words.

23. Keosauqua, Iowa.

24. The body or bed of the wagon.

25. The right side or the side from which the current flowed in this particular case.

26. A traverse bar above the axle of a wagon on which the bed or body or "box" rests.

27. A pioneer place and a post office in the early 1850's in the southwest part of Chequest Township, Van Buren county. ANNals.

28. Lee county, Iowa, 25 miles NNW of Keokuk, Iowa. Lippincott.

29. Lewis and Clark described "two rivers" since the East Chariton (100 miles long) enters the Chariton ( 250 miles) one mile from its mouth. Known also as Charaton, Charitone, and even Theiraton. An Indian name meaning "country rich with honey."

30. Locust creek headwaters in Wayne county, Iowa, and runs southward into Missouri. Enters Grand river in Chariton county. It is about 100 miles long.

31. Morgan Settlement

32. Only three years before the Barnes caravan passed through Princeton was the town platted. Four years after 1849 the town was incorporated. It is the seat of Mercer county, named for Gen. Hugh Mercer of the Revolutionary war battle of Princeton (3 January 1777.)

33. Grand river is a tributary of the Missouri river. Several branches rise in southern Iowa, uniting near Albany in Gentry county, Missouri.

34. Mercer county. 
35. Cabins built of squared logs.

36. Bethany. Only seven years before 1849 had this county been surveyed and only four years previous to this was the county organized. The county was named for A. G. Harrison, a Missouri congressman.

37. Even in 1849 , the resting spot and goal of emigrants to the Far West. This year the U. S. bought the fur trading outpost on the Laramie River, $1 \frac{1 / 2}{2}$ iles from its source, and made it a military outpost.

38. Six thousand emigrants in 600 miles in July, 1849 , averaged 10 persons per mile for one person's estimate of the migration. In 1849 , 296,610 foreign passengers entered U. S. ports while in 1850 , 315,333 came, many of them "heading west." Missouri Historical Review, 18:545, July, 1924, Pritchard, Captain J. A., "Diary of a Journey from Kentucky to California in 1849" records: Friday 11 (May) "By noone to-day we came to where the St. Joseph road \& indipendance road come together-It was allarming to see the long strings of wagons that were on the road-I counted just passing before us as we came into St. Jo road 90 Ox teams in one string-and as far as the Eye could reach forward and back the road was just lined with them-It would appear from the sight before us-that the nation was disgorgeing its self and sending off its whole inhabitance ..."

39. A town in Gentry county, Missouri, on the Grand river, 44 miles $\mathrm{NE}$ of St. Joseph. The Census, 1850, lists 126 inhabitants, "not including the slaves."

40. Mr. Barnes continued to use the "long old English S" for the double " $\mathrm{s}$ " ending in his writings until the 1880 's.

41. The Little Platte rises in Southern Iowa and flows southward for 300 miles to the Missouri river, entering just above Kansas City.

42. For the year ending July, 1850, Missouri produced 16,028 tons of hemp, mostly dew rotted. This was $48 \%$ of the hemp grown in the U. S. that year, being second only to the amount produced by Kentucky.

43. Rochester is on the Platte [Little] river in Andrew county, Missouri, 15 miles NE of St. Joseph.

44. Frolic

45. The capital of Andrew county, Missouri, 14 miles $\mathrm{N}$ of St. Joseph and 6 miles from the Missouri river. Its population in 1850 numbered 654. It was named for Savannah, Georgia, and was the meeting place for Northern and Southern sentiment concerning the slavery question. "The fact that two negroes were sold at auction in in the little town of Savannah aroused them to move on further." Mss.

46. Newark

47. Nodaway river rises in Iowa and runs for 200 miles, entering the Missouri river 20 miles above St. Joseph . . . a corruption of Nad owe-is-iw, of the Sioux meaning "enemy."

48. Probably one of the approximate 80 or a descendant which were removed to near Leavenworth in 1839 after their reservation at the head of Green Bay, Wisconsin, was sold. They agreed to move west of the Mississippi and settled on land near Leavenworth.

49. Founded in 1841 and named after the Oregon Country which was then attracting the first of the long procession of immigrants. Mrs. Barnes referred to it as "Little Oregon."

50. Blue joint Grass [Calamagrostis canadensis] Tall, leafy, slender 
grass growing wild in moist places across the continent in Canada and the northern states. It grows three to five feet tall and is cut for hay.

51. Of Indian origin meaning "walnut" or "place where walnuts grow."

52. An American reed organ, supplanting the English harmonium in the 1850 's. Its reeds sound from inward air current produced by exhaust bellows. The first melodeon patent, \#6543, was issued to C. Austin of Concord, N. H., June 18, 1849.

53. "Mr. Barnes took an active interest in politics in 1840 , being identified with the Liberty party which supported James G. Birney for President. From that time on until the slaves were liberated he was known as an abolitionist." Mss.

54. Through 1893 the U. S. and the Pottawantomie tribe had made 29 separate treaties and 15 joint ones involving other tribes. These 44 treaties totaled $11 \%$ of all Indian treaties the U. S. made. Iowa Historical Record 9:463 "Indian Treaties."

55. Nishnabatona river rises in west-central Iowa and runs into the Missouri River just above the Big Tarkeo.

56. Keg Creek enters the Missouri River 5 miles below the mouth of the Platte after a course through Iowa of 80 miles.

57.

58. Joseph Young was a brother of Brigham Young. He was a quorum leader of the "seventies," the quorum being "instituted for traveling elders to bear record of my name in all the world, wherever the traveling council, my apostles, shall send them to prepare a way before my face." Book of Doctrine \& Covenants, section 107 [Revelation given to Joseph Smith, January 19, 1841,] paragraph 44.

59. "Otaes \& Pawnees roamed about the country" Mss. The Pawnees, living on the Platte in Nebraska, had a plains culture. They raised squash, corn, and beans. The horse was a necessity for them. They were enemies to the Sioux and friendly to the Americans. Lewis and Clark in 1804 describes the Oto as being on the south side of the Platte River thirty miles upstream from its mouth in the Missouri. In 1817 they migrated to the Platte's mouth and to the Pawnees for protection. As late as 1841 at least four Indian villages were in the vicinity. Hodges.

60. October 14, 1849, was the previous Sunday. Here Laura A. Langworthy Barnes records one of the earlier Congregational meetings in central or western Iowa. It was one of the first local meetings not sponsored by the American Home Missionary Society. The Journals show regular meetings from this date until 1 December 1850. I quote the following from a Record Book of the congregation:

"The Record of the Church of Christ in Florence Congregational in Western Iowa. Opposite the Mouth of the Great Platte River. Established on the first day of December in the Year of our Lord One Thousand eight hundred and fifty." "It [Florence] was one of the very few places in Western Iowa where, in 1850, the gospel was not crowded out by Mormonism." Douglass, Pilgrims in Iowa, page 102.

61. Logs that were selected, cut, and in most instances hauled to a particular place for seasoning and for building purposes.

62. "Who remembers California City-in Southwestern Iowa near the Missouri river opposite the mouth of Platte river? When the writer was a rather young child there were still in existence a few posters bearing the caption 


\section{California City}

followed by a few lines of text which cannot now be recalled. In the center four names appeared as follows:

George W. Clark

Waldo M. Tozier

Jack Stuart

These names followed by a few more lines of print. Where was California City? . . . It is the belief of this writer that location either included or was near to the site of the Clark saw mill and settlement, which was almost due west from a point of bluff where Pony creek flowed out from the hills on to the Missouri river bottom ... There was a body of big timber along the river at that time, the site of the Clark Settlement was later a part of the Ben Lincoln homestead." Mss. Forty-five years before Lewis and Clark in their journals described this location as follows:

July 21 [1804]... "We reached in the rain the mouth of the Platte ... The high lands on the west which had accompioned us for the last eight or ten miles stopped at about three quarters of a mile from the entrance of the Platte ... Here is the dividing line between what is called the "upper" and "Lower" Missouri. A number of wolves were seen, and heard around us in the evening.

July 22-26 "we found on the east side a high and shaded situation at a distance of ten miles from the Platte up the Missouri. We camped here ... The hunters have found grain scarce; they have seen deer, turkey, and grouse; we have an abundance of ripe grapes; catfish very common, and easily taken ... green Indian corn ... Ottoe and Pawnee Indian villages.

September 8, 1806 (on the return voyage) ... “Anxious to reach the Platte, we plied our oars so well that by night we had made 73 miles, and landed at our camp of July 22-26, 1804, twelve miles above the Platte ...

September 9, 1806. "By 8 o'clock we passed the Platte; the current of the Missouri becomes more rapid, and the obstructions from fallen timber increase. The river bottoms are extensive, rich, and covered with tall, large timber, which is still more abundant in the ravines."

Florence was a post office in Mills County, Iowa, 1851-1857 with James H. Clark as postmaster. Mereness' List.

Florence (California City) a town WASHED into the Missouri River.

Douglass, Pilgrims of Iowa, 339.

\section{BIBLIOGRAPHY}

\section{ManUSCRIPT Materials}

Barnes, Emma.

Writings ....

Unpublished material by the daughter of Julius Barnes.

Barnes, Julius.

Journal, 1849-1855.

Records four major events: his journey to Iowa, 1849; his first years in Western Iowa; a trip to Missouri in 1867; and a trip to Oregon in the late 1870's.

Barnes, Laura A. and Barnes, Emma.

Journal, 1849-1851.

22 pages of MSS by Laura A., wife of Julius Barnes. Page 24 is blank and page 25 begins page 1 of her daughter, Emma Barnes', diary in 1867.

Journal, 1867-1878. 
Chiefly of Emma Barnes' trip with her father, Julius Barnes, to Missouri in 1867 and to Oregon in the 1870's.

The Record of the Church of Christ in Florence in Western Iowa,

Opposite the mouth of the Great Platte river. Established on the first day of December in the Year of our Lord One Thousand eight hundred and fifty. MS record.

Federal Writers Project.

\section{Books}

Illinois. Chicago, McClurg, c1947.

Iowa. New York, Viking, 1938.

Missouri. New York, Duell, Sloan, \& Pearce, c1941.

Hodge, F. W.

Hand book of American Indians North of Mexico. 2 vol. U. S.,

Bureau of American Ethnology, 1907-1910. (Its Bulletin, \#30)

Lippincott's New Gazatteer. Philadelphia, Lippincott, 1911.

Paullin, Charles O.

Atlas of the Historical Geography of the United States.

Carnegie Institution of Washington, American Geographic Society of New York, 1932.

U. S. Census Bureau.

Seventh Census. (1850)

Eighth Census. (1860)

AnNals of Iowa (Iowa Historical Department) Des Moines. Series 1, $2,3,1863$

Missouri Historical Review (Missouri State Historical Society) Columbia. 1,1906

See also individual titles referred to in the "Notes."

\section{List of STREams and Towns}

As Mentioned in the Journals

STATE Town

Illinois Boyd's Grove, Bureau Co.

$$
\text { Princeville }
$$

Warren

Shawkokwon (Sho-ko-kon)

Iowa

\section{Burlington}

Washington

Theosaqua (Keosauqua)

Mechanicsburg

Dover

Missouri

Morgan Settlement, Mercer County.

Princeton

Seat of Harrison Co.

(Bethany)

Gentryville
Stream

Mississippi river

Des Moines river

Fox river

Chariton river

Locust creek

Grand river, eastern branch

Middle Branch, Grand river

Big creek

Sampon creek

West Fork of Grand river 
Kibbiesville or

Kibbies' Mill

(Rochester)

Savannah

Newark

Oregon

Iowa

New California, or California City, or Florence
Little Platte

Nodaway river

Missouri river

Squaw creek

Little Tarkeo

Big Tarkeo

Rock creek

Nishnabatona river

Keg creek

Mouth of the Big

Platte river

\section{Death of Ora Williams}

As the page proofs of this number of the Annals are being closed, word is received of the death of Ora Williams, former Curator of the Iowa State Department of History and Archives, 1939-1946, and long the editor of the Annals of Iowa, on Friday evening, February 25, 1955, at Decatur, Georgia, at the home of his daughter, Mrs. A. B. Lee. The funeral services are announced to be held in Des Moines with interment at Adel, Iowa, beside his wife, who passed away in 1912. A biographical sketch of Mr. Williams' life will appear in the next issue of the Annals.

\section{The Measure of Greatness}

The greatest man is he who chooses the right with invincible resolution; who resists the sorest temptation from within and without; who bears the heaviest burdens cheerfully; who is calmest in storms, and most fearless under menace and frowns; and whose reliance on truth, on virtue, and on God, is most unfaltering.-Iowa Masonic Bulletin. 
Copyright of Annals of Iowa is the property of State of Iowa, by \& through the State Historical Society of Iowa and its content may not be copied or emailed to multiple sites or posted to a listserv without the copyright holder's express written permission. However, users may print, download, or email articles for individual use. 